\title{
10.5005/jp-joumals-10009-1247 \\ REVIEW ARTICLE \\ Congenital Dacryocystocele: A Rare and Benign Nasolacrimal Duct Cyst Condition
}

\author{
Fernando Bonilla-Musoles, Luis Carlos J imenez, J uan Carlos Castillo
}

\begin{abstract}
Dacryocystocele is an uncommon congenital obliteration of the nasolacrimal drainage system. Based on a case diagnosed at 30 weeks gestation using two-dimensional (2D) and threedimensional (3D), its ultrasound characteristics as well as the evolution and therapeutic options applied in the scarce existing literature are described.
\end{abstract}

Keywords: Dacryocystocele, 2D and 3D ultrasound, Nasolacrimal duct cyst, $\mathrm{P}$ renatal diagnosis.

How to cite this article: Bonilla-Musoles F, J imenez LC, Castillo J C. Congenital Dacryocystocele: A Rare and Benign Nasolacrimal Duct Cyst Condition. Donald School J Ultrasound Obstet Gynecol 2012;6(3):233-236.

\section{Source of support $\mathrm{Nil}$}

Conflict of interest: None declared

\section{INTRODUCTION}

Dacryocystocele, amniocele, amniotocele, lacrimal gland cyst and mucocele are congenital stricture in, or obliteration of, the nasolacrimal drainage system, resulting in a fluidfilled closed sac (mucus, debries and/or amniotic fluid).

It is a rare and benign condition that occurs quite commonly in neonates. ${ }^{1}$

\section{ORIGIN AND ETIOLOGY}

There is al ways a membrane obstruction at the opening of the duct in the nasal cavity (membrane of Hasner) which, if accompanied by proximal stenosis, dilates and forms a dacryocystocele (Fig. 1).

Diagram of the development of the nasolacrimal duct during intrauterine life. The membrane of Hasner depicted in red. To the left, still imperforated (month 7), to the right it is perforated (month 8). Congenital dacryostenosis only
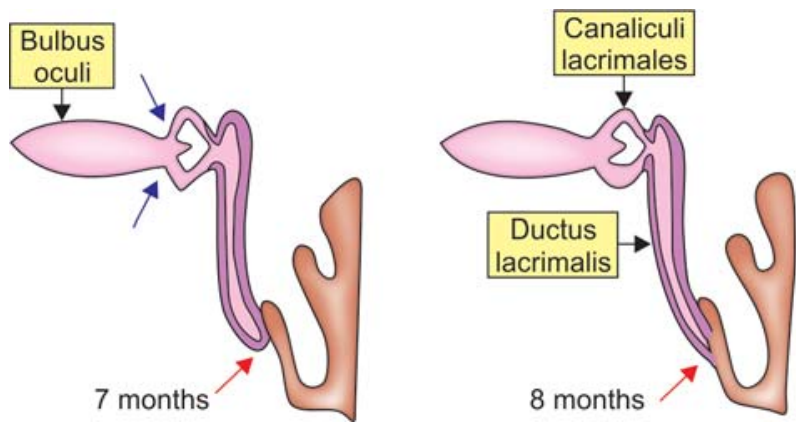

Fig. 1: 2D image. The white arrows show the orbits and dacryocystoceles from a frontal (left), lateral (center) and cranial (right) view. On the right-hand side, DIO -internal interorbitary diameter; DBO-external or biorbital interorbitary diameter appears when there is stenosis or atresia of this membrane. When there is atresia or stenosis of the duct at the orbital level, the so called canaliculi lacrimalis communis, congenital dacryocystocele appears (blue arrows; modified from 2).

The nasolacrimal duct starts to develop toward the 6th week from the epiblast of the basal plaque. As the surface ectoderm in the naso-optic fissure thickens an epithelial cord detaches from it and buries itself between the lateral nasal and maxillary processes. Cephalical and caudal growth of this epithelial cord will give rise to the lacrimal canaliculi, sac and duct. ${ }^{3}$

Canalization commences around week 12 and is not complete until week 24; however, the distal area (nasal) is sometimes only perforated at around the time of birth or even afterward. This permeabilization first starts at the proximal portion of the eye. The opening in the nose takes place between the 7th and 9th months, but the membrane that keeps it closed (Hasner's) continues until the time of birth in 30 to $70 \%$ of cases. ${ }^{2,4}$

\section{ULTRASOUND DIAGNOSIS}

\section{Two-dimensional Image}

Fetal ultrasound scans before 27 weeks are normal and appropriate because the canalization commences around week 12 and is not complete until week 24.

A t week 30 practically all described cases showed with 2D one or two echo-negative round cystic formations, just below the medial canthal area under the orbits, on the inner lower medial line of one or both eyes. The size oscillates between millimeters, in our case measuring 7 and $6 \mathrm{~mm}$, well defined and with no Doppler flow.

The ocular morphology is normal and shows al so normal movement (Fig. 2). In our case, the cysts continued without change at week 33, but in many described cases they disappeared spontaneously during intrauterine life.

In summary their 2D ultrasound characteristics are:

- Hypoechoic periorbital mass

- Located in the lower and medial area of the orbits

- Rounded, with no vascular flows or calcifications, that can be uni- or bilateral

- The eyeball is symmetric, normal, it is not out of place

- Synchronic eye movements can be observed

- Exhibiting normal brain and facial structures. 


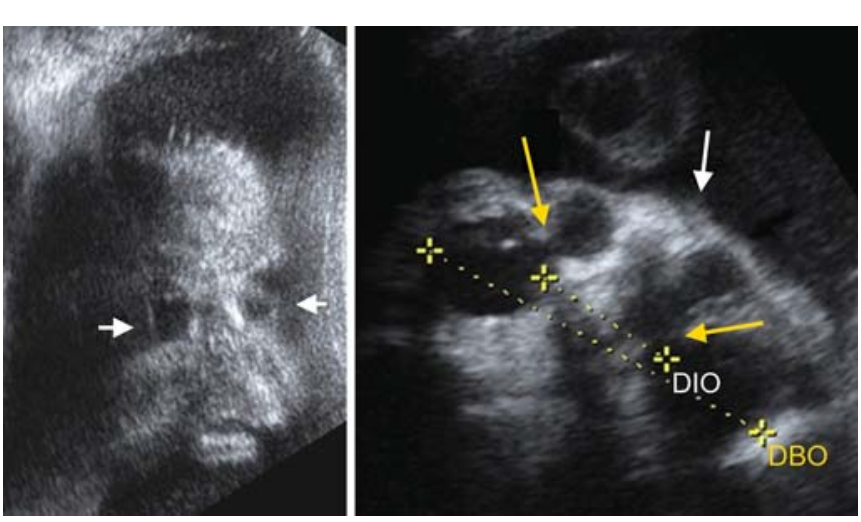

Fig. 2: 3D surface image. Above, frontal view of the face showing eyes closed and two tumors. Below, side view of the surface of the nose, eye and dacryocystocele (red arrow). Also, the face of the newborn showing two blue tumors (red arrows)

All these characteristics make difficult to confuse this anomaly with other facial masses distorting the fetal face 2D image left. The white arrows show the orbits and dacryocystoceles from a frontal (left) and cranial (right) view. On the right-hand side $\mathrm{DIO}=$ internal interorbitary diameter; DBO = external or biorbital interorbitary diameter. The white arrow shows a small but evident swelling of the subcutaneous tissue. The yellow arrows show the communication between the cystis paraocular mass and the orbit.

In view of the diagnosis of dacryocystocele, we resorted to surface three-dimensional (3D).

\section{D Image}

When using 3D, the following advantages where observed:

- Clearly depicted and identified the anomaly, and allowed to determine both the precise location of the cysts and the degree of intranasal extension. 5,6

- B oth tumors were clearly observed under the eyes, next to the nose. The cysts were sharply defined when region of interest (ROI) was applied to the tumor site (Fig. 3).

- Showed the degree of intranasal extension and the communication with the orbits (Figs 1 and 3, above left)

- Surface-rendering imaging showed swelling below the medial canthal area. ${ }^{6}$

- M ake much clearer parents understanding of the anomaly. ${ }^{5}$ 3D surface image. Above, frontal view of the face showing eyes closed and two tumors. Below, side view of the surface of the nose, eye and dacryocystocele (red arrow, showing also the communication between cyst and orbit). A lso the face of the newborn showing two blue tumors (red arrows). They disappeared when just simple digital pressure was applied.

\section{COMMENTS AND CLINICAL EVOLUTION}

There are two different entities as follows:

- Dacryocystostenosis: A tresia of the membrane or valve of Hasner (Fig. 1, red arrows) is the main cause. The estimated incidence is 6 to $73 \%$ but only 2 to $4 \%$ are symptomatic

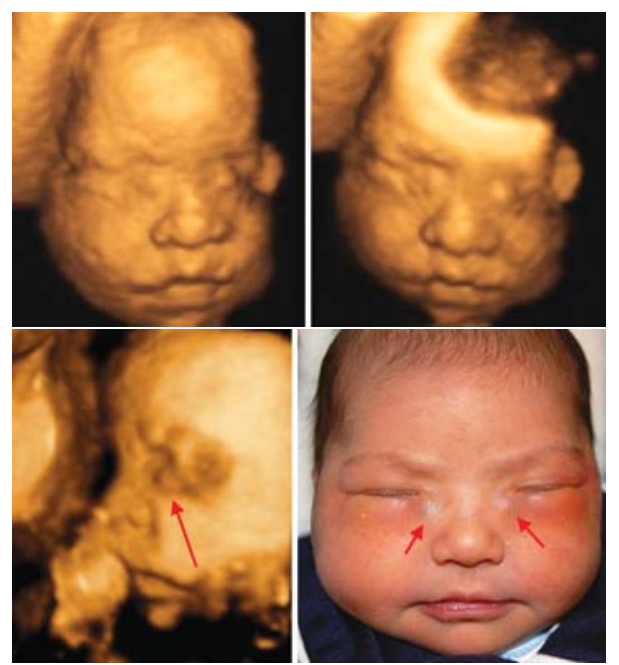

Fig. 3: Diagram of the development of the nasolacrimal duct during intrauterine life. The membrane of Hasner depicted in red. To the left, still imperforated (month 7), to the right, it is perforated (month 8). Congenital dacryostenosis only appears when there is stenosis or atresia of this membrane. When there is atresia or stenosis of the duct at the orbital level, the so-called canaliculi lacrimalis communis, congenital dacryocystocele appears (blue arrows). (Modified from ref. 12)

and the symptoms appear between 10 and 30 days after birth. ${ }^{4}$ In most cases perforation is spontaneous.

- Dacryocystoceles are much less usual; there is always an additional functional obstruction in the lacrimal sac near the orbit (Rosenmüller's membrane; Fig. 1, blue arrows). They are practically always symptomatic at birth or shortly afterward.

Newborns show no symptoms (only $6 \%)^{7}$ or such symptoms are very slight, and because of spontaneous resolution (78\% at 3 months and $91 \%$ at 6 months) it is not considered as being a serious condition. ${ }^{8}$

Only few references have resulted in neonatal respiratory distress requiring surgical intervention. ${ }^{9,10}$

\section{About Ultrasound}

The majority of prenatal reported cases using 2D ultrasound (US) have been isolated cases. ${ }^{4,9,11-21}$ Nevertheless, two series with six (1) and ten cases (6) respectively have been published.

Although some other cases have been reported as prenatal diagnosis, many belong to postnatal controlled series (ref. 10: 54 cases, ref. 2:3 cases, ref. 7: 21 cases, ref. 8: 4 cases, ref. 22: 4 cases, ref. 4: 5 cases).

Cases using 3D US are very scarce, appeared more recently and showed the diagnostic importance of this new technology ${ }^{5,6,23}$ which includes simultaneous orthogonal views, multiplanar plane slicing and rotation and surface rendering.

\section{Prevalence and Clinical Evolution}

As most cases are mild, or more commonly resolve spontaneously in intrauterine life at the end of the pregnancy or during the immediate neonatal period, their prevalence 
is unknown and is probably very much greater than reported by the literature. Table 1 summarizes the 34 cases diagnosed prenatally with US and show their clinical evolution.

All the cases were diagnosed after week 27 (one case); and usually they are not described before 30 weeks because the canalization may not be complete.

Some were transitory (18 cases) and disappeared during intrauterine life, others persisted.

Thesizeis al ways small and ranged between 3 and $13 \mathrm{~mm}$. They wereall hypoechoic (32 cases) or gray echoes ( 2 cases gray orwith debries 6); and theshapewerealways rounded or oval.

It was reported that they appeared alone, unilaterally $(90 \%)$, on either side, only $13 \%$ were bilateral ${ }^{23}$ and predominantly in female fetuses. ${ }^{1,4,6,10,12,15}$
Our review shows that $47 \%$ were bilateral and only five out of 34 were male newborns.

It has been reported that they may accompany other malformation syndromes, such as ectrodactyly-ectodermal dysplasia-clefting (EEC), down, craniofacial anomalies, multicystic kidney disease, ${ }^{2}$ microftalmia, palatoschisis, spheroidal meningocele and hydrocele. ${ }^{10}$ However, we only encountered one case, a baby that died 6 months after birth from Canavan syndrome $e^{1}$ and three cases were described with polyhydramnios, ${ }^{11,17}$ but tw 0 of them ${ }^{11}$ did not show an excess of amniotic fluid at the time of delivery. Hence, reports on accompanying syndromes have not been proven, at least in fetal life.

Table 1: Description of published cases

\begin{tabular}{|c|c|c|c|c|c|c|c|c|c|}
\hline Authors & Years & Cases & $\begin{array}{l}\text { Week at } \\
\text { diagnosis }\end{array}$ & $\begin{array}{l}\text { Maternal } \\
\text { age }\end{array}$ & Gravida & Para & Lesion & Outcome T/P & Comments \\
\hline Davis & 1987 & $\begin{array}{l}1 \\
2\end{array}$ & $\begin{array}{l}33 \\
30\end{array}$ & $\begin{array}{l}30 \\
25\end{array}$ & $\begin{array}{l}1 \\
1\end{array}$ & $\begin{array}{l}0 \\
0\end{array}$ & $\begin{array}{l}8 \mathrm{~mm}, \mathrm{R} \\
13 \mathrm{~mm}, \mathrm{R}\end{array}$ & $\begin{array}{l}\text { Healthy, T, polyhydramnios } \\
\text { Healthy, P, polyhydramnios }\end{array}$ & $\begin{array}{l}\text { Female } \\
?\end{array}$ \\
\hline Schaub & 1992 & 1 & 32 & $?$ & $?$ & $?$ & B & & \\
\hline Schaub & 1992 & 1 & 32 & 34 & 3 & 2 & $10 / 8 \mathrm{~mm}, \mathrm{~B}$ & Healthy, $T$ & Male \\
\hline Alpert & 1994 & 1 & 34 & 31 & 4 & 2 & $9 / 8 \mathrm{~mm}, \mathrm{~B}$ & Twins healthy, $P$ & Surgery \\
\hline Walsh & 1994 & 1 & 36 & 17 & 3 & 0 & $11 / 5 \mathrm{~mm}, \mathrm{~B}$ & Healthy, P & Female \\
\hline \multirow[t]{2}{*}{ Batagglia } & 1994 & 1 & 33 & 26 & 1 & 0 & $11 \mathrm{~mm}, \mathrm{~L}$ & Healthy, $T$ & Female \\
\hline & & 2 & 32 & 36 & 1 & 0 & $9 \mathrm{~mm}, \mathrm{~L}$ & Healthy, $T$ & Female \\
\hline Shipp & 1995 & 1 & 34 & $?$ & $?$ & $?$ & $?, \mathrm{~B}$ & Healthy, P & $?$ \\
\hline Sherer & 1997 & 1 & 32 & 31 & 1 & 0 & $9 \mathrm{~mm}, \mathrm{R}$ & Healthy, P & Female \\
\hline \multirow{4}{*}{ Kivikoski } & 1997 & 1 & 32 & 27 & 7 & 5 & $7 / 5 \mathrm{~mm}, \mathrm{~B}$ & Healthy, P, polyhydramnios & $?$ \\
\hline & & 1 & 27 & 28 & 1 & 0 & $10 \mathrm{~mm}, \mathrm{R}$ & Died 6 months, $\mathrm{P}^{*}$ & Canavan, ? \\
\hline & & 2 & 29 & 40 & 4 & 1 & $4 \mathrm{~mm}, \mathrm{R}$ & Healthy, P* & IVF, ? \\
\hline & & 3 & 28 & 27 & 5 & 4 & $6 \mathrm{~mm}, \mathrm{~L}$ & Healthy, P* & $?$ \\
\hline \multirow[t]{3}{*}{ Sharony } & 1999 & 4 & 28 & 40 & 6 & 3 & $5 / 3 \mathrm{~mm}, \mathrm{~B}$ & Healthy, P* & Diabetes, ? \\
\hline & & 5 & 36 & 26 & 1 & 0 & $10 / 4 \mathrm{~mm}, \mathrm{~B}$ & Healthy, P* & Pyelectasis, ? \\
\hline & & 6 & 29 & 21 & 1 & 0 & $4 \mathrm{~mm}, \mathrm{~L}$ & Healthy, P* & MCKD, ? \\
\hline Suma & 1999 & 1 & 32 & 29 & 1 & 1 & $1.1 \times 0.8, \mathrm{R}$ & Healthy & Drenaje male \\
\hline Salvetat & 1999 & 1 & 38 & 28 & 2 & 1 & $8.1 / 10.1, \mathrm{~B}$ & Healthy, P & $\begin{array}{l}\text { ? Spontaneous } \\
x \text { drenaje }\end{array}$ \\
\hline Goldberg & 2000 & 1 & 34 & 33 & 1 & 0 & $10 / 11, \mathrm{~B}$ & Healthy, P & $\begin{array}{l}\text { Female } \\
\text { massage }\end{array}$ \\
\hline D 'Addario & 2001 & 1 & 34 & 33 & 4 & 3 & $8, R$ & Healthy & $\begin{array}{l}\text { Female } \\
\text { spontaneous } \\
\text { resolution }\end{array}$ \\
\hline \multirow[t]{5}{*}{ Petrikovsky } & 2003 & 1 & 31 & $?$ & $?$ & $?$ & $?, \mathrm{~B}$ & Healthy, P & $\begin{array}{l}\text { ? Spontaneous } \\
6 \text { months }\end{array}$ \\
\hline & & 1 & 27 & 34 & & & $7 \mathrm{~mm}, \mathrm{R}$ & Healthy, $T$ & 8 females \\
\hline & & 2 & 31 & 33 & & & $7 \mathrm{~mm}, \mathrm{R}$ & Healthy, $T$ & \\
\hline & & 3 & 33 & 34 & & & $8 \mathrm{~mm}, \mathrm{~L}$ & Healthy, $T$ & \\
\hline & & 4 & 28 & 39 & & & $7 / 7 \mathrm{~mm}, \mathrm{~B}$ & Healthy, $T$ & \\
\hline \multirow[t]{6}{*}{ Sepulveda } & 2005 & 5 & 30 & 27 & 6 & & $7 / 4 \mathrm{~mm}, \mathrm{~B}$ & Healthy, $T$ & \\
\hline & & 6 & 32 & 32 & nulliparous & & $9 / 7 \mathrm{~mm}, \mathrm{~B}$ & Healthy, $T$ & \\
\hline & & 7 & 30 & 26 & & & $8 \mathrm{~mm}, \mathrm{R}$ & Healthy & Massage \\
\hline & & 8 & 31 & 30 & & & $10 \mathrm{~mm}, \mathrm{~L}$ & Healthy & Massage \\
\hline & & 9 & 30 & 24 & & & $7 \mathrm{~mm}, \mathrm{~L}$ & Healthy & Massage \\
\hline & & 10 & 29 & 27 & & & $11 / 6 \mathrm{~mm}$ & Healthy & $\begin{array}{l}\text { Spontaneous } \\
\text { unilateral }\end{array}$ \\
\hline Brown & 2011 & 1 & 28 & 30 & 1 & 0 & $5 / 7 \mathrm{~mm}, \mathrm{~B}$ & Healthy, $T$ & 3D, male \\
\hline Bonilla & 2012 & 1 & 30 & 22 & 1 & 0 & $7 / 6 \mathrm{~mm}, \mathrm{~B}$ & Healthy, P & $3 \mathrm{D}$, female \\
\hline Total & & 34 & $27-38$ & $17-40$ & $1-7$ & $0-5$ & $\begin{array}{l}3-13 \\
16 B\end{array}$ & $16 P$ & 5 \\
\hline
\end{tabular}

R: R ight; L: Left; B: B ilateral; P:Persistent; T:Transient; ?: G ender or size notspecified; *Sharony: Nondescribed; $2 \mathrm{P} ; 2 \mathrm{~T} ; 1$ evacuan y 1 draineage 
The progressive accumulation of mucus secretion leads to cystic dilation of the duct and as the nasal bones are still very soft, a bulge may appear which, in extreme cases, can hinder or obstruct breathing. ${ }^{2}$

All with 3D-reported articles [ref. 5 (one case), ref. 6 (three cases), ref. 23 (one case)], showed that the image was much better, with greater definition, more exact localization, volumetric calculation, determination of size, spatial demarcation and orientation and, therefore, it was much better for giving advice to the parents.

This was exactly the same in our case; 3D vision defined much better and made all differential diagnoses easier.

The literature stresses that differential diagnoses should be performed with inflammations (canaliculitis, dacryocystitis, rhinitis), obstructions (atresia or choanal stenosis), anterior encephalocele, meningocele, teratomas, hemangiomas, gliomas and rhabdomyosarcoma, neurofibromatosis and lymphangiomas. ${ }^{1,2,15,22}$

The complications described have been dacryocystitis, orbital celulitis and respiratory distress due to extension of the cyst in the nasal cavities.

Treatment: Those that persist do not usually pose a problem and at birth present taut, firm, gray-blue mass just below the lower ocular angle and medial to the orbits. The impatency of the nasolacrimal duct is a result of the thin mucosa that obstructs and usually perforates spontaneously, or with gentle massage, at birth. T reatment options include only observation and monitoring for 6 months (sufficient in the vast majority of cases). Hot compresses and/or topical antibiotics, anterograde massage and nasal probing and drainage, if necessary, are further options. ${ }^{2,4,10}$ After 6 months all the subjects, except for the case with Cavanan syndrome, were alive and free from tumors.

In our review four cases needed massage, two cases drainage and in only one case surgery was required. A fter birth or 6 months later $77 \%$ of all described cases were healthy without any treatment.

\section{REFERENCES}

1. Sharony R, Raz J, A viram R, et al. Prenatal diagnosis of dacryocystocele: A possible marker for syndromes. Ultrasound Obstet Gynecol 1999;14:71.

2. Hübsch $S, A$ Izen $G, K$ limek $T$, et al. Pathophysiologie, diagnose und therapie von drei kongenitalen Dakryozystozelen. Klin M onatsbl A ugenheilk 2000;217:59.

3. Sevel D. Development and congenital abnormalities of the nasolacrimal apparatus. J Pediatr Ophthalmol Strabismus 1981;18:13.

4. Schlenck B, U nsinn K, G eley T, et al. Sonographische Diagnose kongenitaler Dakryozystozelen. U Itraschall M ed 2002;23:181.

5. Petrikovsky BM , K aplan GP. Fetal dacryocystocel e: Comparing 2D and 3D imaging. Pediatr Radiol 2003;33:582-83.
6. Sepulveda W, W ojakowski A B, Elias D, O taño L, Gutierrez J. Congenital dacryocystocele. Prenatal 2- and 3-dimensional sonographical findings. J U Itrasound M ed 2005;24:225-30.

7. Hepler KM, Woodson GE, K earns DB. Respiratory distress in the neonate. Sequela of a congenital dacryocystocele. Arch Otolaryngol Head Neck Surg 1995;121:1423.

8. Harris GJ, Clementi D. Congenital dacriocystocele. A rch Ophtalmol 1982;100:1763.

9. Alper CM , Chan K H, Hill L M , Chenevey P. A ntenatal diagnosis of a congenital nasolacrimal duct cyst by ultrasonography: A case report. Prenat Diagn 1994:14:623-26.

10. M ansour A M , Cheng K P, M umma JV, etal. Congenital dacryocele. A collaborative review. O phthalmology 1991; 98:1744

11. Davis WK, M ahony BS, Carroll BA, et al. A ntenatal sonographic detection of benign dacrocystoceles (lagrimal duct cysts). J Ultrasound M ed 1987;6:461.

12. Schaub B, Sainte-Rose D. D acryocystocele: Diagnostic antenatal ecographique. J Gynecol Obstet Biol Reprod 1992;21:82.

13. Walsh $G$, Dubbins PA. A ntenatal sonographic diagnosis of a dacryocystocele. J Clin Ultrasound 1994;22:457.

14. Battaglia C, A rtini PG, D 'A mbrogio G, et al. Prenatal ultrasonographic evidence of transient dacryocystoceles. J Ultrasound M ed 1994;13;897.

15. Shipp TD, Bromley B, B enacerraf B. The Sonographic apperance and outcome for fetuses with masses distorting the fetal face. J Ultrasoud M ed 1995;14:673.

16. Sherer DM, Eisenberg D, Schwartz BM, et al. Prenatal sonographic diagnosis of dacryocystocele: A case and review of the literature. A m J Perinatol 1997;14:479.

17. Kivikoski AI, A min N, Cornell C. A ntenatal sonographic diagnosis of dacryocystocele. J M aternal Fetal M edicine 1997;6:273.

18. Suma V, M arini A, Bellitti F, Bucci N, Dorov D. Prenatal sonographic diagnosis of dacryocystocele. Ultrasound Obstet Gynecol 1999;14:74.

19. Salvetat M L, D 'Ottavio G, Pensiero S, V inciguerra A, Perissutti P. Prenatal sonographic detection of a bilateral dacryocystocele. J Pediatr O phthalmol Strabismus 1999:36:295-97.

20. Goldberg H, Sebire NJ, Holwell D, Hill S. Prenatal diagnosis of bilateral dacrocystoceles. UItrasound Obstet Gynecol 2000;15:448-49.

21. D 'A ddario V, Pinto V, A nfossi A, Del Bianco A, Cantatore F. A ntenatal sonographic diagnosis of dacryocystocele. Acta Ophthalmol Scand 2001;79:330-31.

22. Rand PK, Ball WS, Kulwin DR. Congenital nasolacrimal mucoceles: CT evaluation. Radiology 1999;173:691.

23. Brown K, A dhate A, A puzzio J. Prenatal diagnosis of bilateral dacryocystocele using 3D/4D ultrasound technology. J Reprod Med 2011:5:78.

\section{ABOUT THE AUTHORS}

\section{Fernando Bonilla-Musoles (Corresponding Author)}

Professor and Chairman, Department of Obstetrics and Gynecology University of $\mathrm{V}$ alencia School of M edicine, A venida B lasco Ibáñez 17 46011 V al encia, Spain, e-mail: profesorbonillamusoles@ hotmail.com

\section{Luis Carlos J imenez}

Professor of U Itrasound, Department of Obstetrics and Gynecology University of Colombia, B ogota, Colombia

\section{J uan Carlos Castillo}

Department of Obstetrics and Gynecology, U niversity of $\mathrm{V}$ alencia School of M edicine, A venida Blasco I báñez 17, 46011 Valencia, Spain 